\title{
ALTERED ISLANDS: YOUNG FAROE ISLANDERS' FUTURE LANDSCAPES
}

\begin{abstract}
This paper explores scenarios created by young Faroe Islanders reflecting on the future of their local community and islands. The main objective is to outline and analyse the dynamic relationship between young people's future images and present-day realities. Based on data from an ethnographic study from 2014, the paper discusses young people's futureoriented essays in relation to their islands' history, culture, and values. The essays, as methodological schemes, encourage the youth to draw a 'future landscape' without necessarily linking it directly to their personal (intimate) perspectives. They offer an opportunity to discuss the relation between micro- and macro-level events and between material and cultural shifts. In these narratives, we notice a strong commitment to connect the future to the past in a collective Faroese project. The future is often drawn as altered islands-a mesmerizing breakaway from present-day realities. The opportunity to dream and to imagine tomorrow is an important part of young people's everyday life practices and identities.
\end{abstract}

Keywords: futures, young people, islands, narratives, imagination, temporality, history

\section{INTRODUCTION}

In this article, the future of the Faroe Islands is examined through the lens of young people's narratives and perspectives. The aim is to outline and analyse the dynamic relationship between young people's future images and present-day realities. Hovering between bright and dark expectations, between utopian and dystopian visions, they narrate the near future as altered islands, a place shaped by today's practices and decisions. Traditionally, Faroe Islanders used 'the past to make sense of the present', says Wylie
(1982: 456-457), but what do they say about the future today? From a continental European perspective, the Faroes is normally viewed as a periphery, but the youth of the islands do not feel less modern for this reason (Gaini 2008). Already at the age of $14-16$, Faroe Islanders have many reflections and narratives about their future. They cannot predict the future; yet each and every one of them is a source of ideas and scenarios. These ideas and scenarios not only differ from the typical forecast voiced by adult 'experts', but also expose future imaginations along a wide array of puzzling 
trajectories. Some of them are pessimists, others are optimists, but most of them seem to agree that deep societal change is impending (Gaini 2015). When you think about the huge societal developments of the $20^{\text {th }}$ century (especially since the 1950s and 1960s), it cannot really come as a surprise that young Faroe Islanders await irrevocable transformation of their society (ibid.) Who would, for instance, have believed in undersea tunnels connecting islands 40 years ago? Young people seem to have a kaleidoscopic view of the future offering alternative paths leading in different direction, rather than a deterministic view of an unavoidable future scenario.

After a brief introduction to key anthropological discussions on the future(s) and the methodological framework of my ethnographic project, I will present the context with focus on the interpretation of history and the role of temporal dimensions of Faroese culture in relation to future imagination. Then I present and analyse young people's future landscapes along three strands: the themes of family, culture, and technology. Finally, I summarize the findings and reflect on the future as altered islands - and future imagination as a part the identity struggle of islanders.

\section{FUTURES IN ANTHROPOLOGY}

Anthropologists have always engaged with the future-or rather futurity - as an underlying temporal element in their ethnographic work, but the future was remarkably absent as a theme and special object of research up to the end of twentieth century (e.g. Persoon and van Est 2000; Austdal and Helgesen 2015; Salazar et al. [eds] 2017). The past seemed palpable, the future rather intricate, and, especially in the cyclical time model associated with nonWestern societies, the future was taken for granted (Wallman [ed.] 1992). Margaret Mead's 'A Note on Contributions of Anthropology to the Science of the Future' (1971) represents an early anthropological review of the future, but the impact of her work, considered 'nonscientific' by leading scholars, was limited (Pink and Salazar 2017: 6). While many economists, social psychologists, education researchers, and others joined the emerging future research brigade in the 1970s and 1980s, best exemplified by Alvin Toffler's bestseller Future Shock (1970), anthropologists generally restrained from the future as an approach to understanding society (Valentine 2012).

Nonetheless, from the late 1990s onwards, a small yet growing number of anthropologists felt the urge to react against models of 'empty' futures, where the future was the subject of unhampered exploitation and control, and which overlooked the future's relation to present-day practice and action (Urry 2016: $7-10)$. It is time for the social scientists to reclaim the future, says John Urry (ibid.), and hence to escape what Anna Tsing (2005) has described as neoliberal globalization's 'shadow of inevitability' over future imagination. With the future released from the monopoly of authoritative categorical forecasts in the beginning of the $21^{\text {st }}$ century (often in the form of scenario construction involving controversial futures), anthropological and sociological future-focused studies grounded on present-day social realities have emerged. The moment, says Tim Ingold (1993: 159), gathers 'the past and the future into itself, like refractions in a crystal ball'. However, if we cannot spot the refractions, we need to ask people about their future images and perspectives-what do they dream and aspire, hope and expect? Today it is not so much a quest for utopia as it is a route to a less evil world (Bauman 2006: 320). Young people, reflecting on their lives and goals, are 'thinking 
and dreaming the materials of new tomorrows' (Polak 1973). They have images of the future, which frame future scenarios, and these serve as active elements in young people's concrete present-day practices (Austdal and Helgesen 2015: 212-216). Contrary to prediction, which 'just' soberly projects present processes onto the future, future images and scenarios can include unexpected events (even what might seem quite ridiculous) based on 'what if' contemplation (Staley 2002: 74).

The concept of scenario is common in future studies analysis, which draws inspiration from various disciplines (Cole 2001). Future scenarios are imaginative speculation, not prophesy, says Nicholas Rescher (in Staley 2002: 81) critically, but scenarios have other qualities and purposes. Among other things, scenarios help us sketch the forces which can direct the future in different directions (Schwartz in Staley 2002: 79). Anthropologists, on the other hand, are more interested in 'contemporary futures' and aim to review the 'causes and consequences of images of the future in specific contexts of time and place' (Persoon and van Est 2000: 22). Young people's contrasting images of the future, therefore, directly or indirectly, comment on a wide range of everyday life aspects reflecting their sense of belonging and cultural identity, family, and social network, as well as education and knowledge (Galland 2008).

The social psychology literature on youth future narratives, which largely builds on Erikson's (1964) model of developmental stages, presents adolescents as subjects creating accounts on adulthood transition and the life course. They create narratives of the future 'reflecting the beliefs they hold about what events and experiences should happen in their lives and when' (Greene and Wheatley 1992: 668). These studies, focusing on individualized life course progression, do not look at young people's creative and critical narratives of society in general. Scenario writing, based on future thinking or imagining, is an act of being human, an expansion of one's horizon, but it is also, says Wallman (1992), a safe way of criticising the present (Abram 2017: 77-78). Fixating future dates-for scenarios-is an interesting technique in research on young people's future images, opening up for ordinary prediction as well as outlandish visions (ibid. 75). Later, this temporally fixed future will become the past. One way of opening the way for radical and provocative visions of alternative presents is by 'othering' the future. From this perspective, the future is imagined as 'alterity of the present, rather than as a distant eventuality' (Pink et al. 2017: 133). This approach might lead to artistic projects employing unconventional research methods, but it can also be a matter of experimentation with knowledge and sentiments in imagined future constellations.

\section{FRAMEWORK AND FOCUS}

In May 2014, I established a research collaboration with two groups of eighth graders (aged 14-15) in the Faroes ${ }^{1}$. Together with my research assistant Ester Áarskarð, I conducted 21 and 19 interviews with pupils from Eysturoy Island and Torshavn (the capital) respectively. In addition to the semi-structured interviews, we organized essay-writing assignments with the same groups. We received 17 and 25 essays from Eysturoy Island and Torshavn respectively. The town in Eysturoy Island, called East Town here, is part of a municipality of 3,500 inhabitants, while the municipality of Torshavn has 21,000 inhabitants. My aim was to include participants from the main urban centre as well as from a regional town. Choice fell on East Town because of its strong link to small neighbouring villages (some of its pupils have a background 
in village schools). East Town is a dynamic community with a variety of services and businesses, making it rather prosperous and independent from the capital. The personal essays, written and submitted before the interviews took place, were guided by this introduction (translated from Faroese):

\section{Faroe Islands 2045}

Imagine that you travel in time and arrive to the year of 2045. You meet an eighth grader. He tells you how it is to live in the Faroe Islands in 2045-about school, leisure, family-life, culture, etc.-and you take notes. In this essay, we want you to write the story of this youth. You are welcome to compare your own everyday life with the life of the youth living in 2045.

This is an invitation to reflect on future young Faroe Islanders' everyday lives and identities, when the research participants themselves have reached the age of 45 or 46 . The essays, as methodological schemes, encourage the youth to draw a future landscape without necessarily linking it directly to their personal (intimate) perspectives. In this way, the essays offer an opportunity to discuss the relation between micro- and macro-level events and between material and cultural shift. Another important objective is to use essays to produce a dialogue between today (2014) and tomorrow (2045), hence also to present a constructed future reaction to present-day problems. Another benefit of this method is that it encourages young people to develop new creative writing and critical thinking skills (Trell and Van Hoven 2010: 93). The mix of methods-a two-tier approach of individual interviews and essays-helped participants, or co-workers (co-researchers), feel that they had an active role in the project, because the interview setting was an opportunity to reflect and comment on their own essays about the Faroes in 2045.

The essay represents a kind of 'mental mapping' with temporal rather than spatial components. As method, the essays also minimize the pressure of concrete questioning and emancipate the participants' future 'worlding' (Knight 2017: 84). Rather than illustrating the present and future in real/unreal oppositions, the essays can be read and analysed through the optic of an ongoing generative process (ibid.). When I was interpreting and analysing the pupils' texts, which count from 300 to 1,500 words, I focused on their open and covered messages about the positive and negative aspects of potential developments in society. Working with the essays as ethnographic material, my aim was to search for young people's cultural identities and values through their future narratives. From the context of the Faroe Islands, which has been defined as a society with high level of trust and bounded solidarity (Hayfield 2017), I was also interested in the role of the past-history and myth-in future projections: in which way do the past and the future refer to each other in relation to present-day tendencies?

All translations from Faroese to English in this text are mine, and the names of the participants have been changed. All essays were originally written in Faroese language.

\section{FUTURES AND TEMPORAL LANDSCAPES}

The Faroe Islanders, some 51,000 people, inhabit the basaltic North Atlantic archipelago of the Faroe Islands, 650 kilometres from the Norwegian west coast. Their native language is a west-Nordic language rooted in ancient Norse $^{2}$. The Faroes is commonly portrayed as a quite sensitive and fragile society in media, as a place, which needs to protect itself in the 
so-called age of globalization. This is usually explained as an effect of its small scale and relative seclusion. At the same time, the Faroes is an example of a small island community, which seems to have had great success in its adaptation to new structures of economic opportunities. It is today a dynamic society characterized by high standards of living, a high level of education, an ultramodern fishing industry, and a Scandinavian-style public welfare system (Hovgaard and Apostle 2002) . $^{3}$ As a heavily fisheries depended economy, fluctuation is always a part of the game. The labour market is considered highly flexible with effective transitional forces between industries (FEC 2012). In this environment, with economic, social, and cultural continuities and discontinuities, young people draw their future images. But what can we say here, briefly, about the temporal landscape of the islands through history?

Exposed to the exceptionally unpredictable and incalculable Elements of the North Atlantic, Faroe Islanders' everyday practices and enterprises could be nothing but (temporally) conditional and negotiable until the $20^{\text {th }}$ century. It was-and to some extent still is-difficult to make plans with a fixed time limit. The new abstract clock time could not easily negate the capricious forces of nature, which engaged the islanders in sophisticated discussions of natural and supernatural signs telling tomorrow's weather. Ignoring alarming signals in order to save time-for instance when traveling between villages and islands-could obviously be fatal. The old saying (among seafarers in the Faroes and beyond) 'only a fool does not fear the sea' was indeed relevant for anyone wayfaring in the Faroe Islands. You did not need to take the role of an outright fool to end up in an unfortunate and dangerous position, because risk and uncertainty were embedded in any venture in nature. There is some truth to the claim that there is no word Faroe Islanders use as much as 'maybe' (kanska in Faroese). An attentive Englishman even called the islands 'Land of Maybe' in an amusing and well-received essay (Norgate 1943). Faroe Islanders, he says, are 'ruled under despotismthe not so benevolent despotism of the weather'. Subjects to this context, they stick the kanska to future programs, pending a favourable moment: 'maybe we'll go fishing tomorrow-maybe we'll try to do a bit of haymaking-maybe we'll get married' (ibid.: 3$)^{4}$.

Faroe Islanders' 'temporal orientation is fluid, but deep', says Gaffin, and 'exactitude in time' is much less important than 'exactitude in space' (Gaffin 1996: 226). This perspective fits to Gaffin's cultural ecological representation of a Faroese village community with rich oral traditions. In the Faroes, he says, existence represents a peculiar blend of 'known elements of nature and humanity with the ultimately unpredictable and enigmatic' (ibid.: 225). This synthesis, you could say, is a premise for the islanders' interpretation of new events with 'preexisting as well as ongoing images in mind', and, Gaffin argues, what lasts are the 'symbolic meanings' of the stories and accounts (ibid.: 222-223). Faroe Islanders, in other words, use creativity and oral communication about the past and present in order to define the spatial and social order and integrity of their local community. The islands are mystical and the islanders are living legends, Gaffin ponders, with an image-creating approach to history. In the islanders' everyday communication, says Wylie, 'history' has an intriguing role and meaning. Among the islanders, he says,

historiographic and literary affairs are as important as, say, kinship is among the peoples anthropologists usually study. It is quite certain that the survival of the 
distinctively Faroese culture through the great social changes of the late nineteenth and early twentieth centuries depended upon the reformulation of an acute literary and historical self-consciousness. (Wylie 1987: 3)

Before the modern era, the islanders were not particularly preoccupied with future scenarios of radical shift from status quo (except in the relation to the messianic Paradise of Christian faith). The smooth rhythm of social life, with its rituals and ceremonies, its symbolic boundaries and bridges, represented motions in what can be called a 'temporal scenery' (Ingold 1993: 159160). The rhythmic cycles of life and nature, as 'complex temporal nexus' (Hirsch and Stewart 2005), did not really invite for dystopian/utopian future images. The future was mirrored in the past, and vice versa, and the place-the island in the temporal sea-was defined through the tales and legends, ballads and poems. This was before the modernization of society in the $19^{\text {th }}$ century, when the future became part of a new national project of (planned) growth. Let us now take a closer look at the future landscapes of contemporary Faroese youth along three strands illustrating continuities and discontinuities in their temporal narratives: family, culture, and technology.

\section{FAMILY FUTURES}

The idea of the Faroese family as fulcrum of society represents a cultural pendulum, or Archimedean (fixed) point, which young people use to narrate the interplay between the past and future of the Faroes. What is a family? This question, which seems increasingly complex in nature, is the subject of critical discussion and imagining in almost all of the essays. In the Faroes, which has been described as a religious-conservative and family-oriented society, it seems to be 'safer' and less binding to review the contemporary dissonance between dominant family ideals and social realities through future imagination than by straightforward testimony. In the essays, which in many cases have the form of the travelogue (with 2045 as exotic faraway destination), young people confront and break familiar taboos with the help of future family envisioning. Cindy from Torshavn says in her essay:

The family is not nuclear in 2045. In 2045, more and more people live alone, and more and more parents let the children do what they want. Parents work more and more, and children are more and more alone. And because of this, parents and children spend less and less time together.

In her perspective, a trend which has already started, and which is evolving while she draws her sombre future scenario about asocial individuals losing their sense of togetherness, might get 'much worse' in 2045. In Zoe's essay, we meet the character Sarah, who is the interviewee of a time traveller from Torshavn:

Hey, my name is Sarah, I am fifteen, and I am a student in the eighth grade in Western School (Torshavn). I live in Torshavn (...) In my spare time, I dance, sit by the computer, and watch TV. My dream is to become a History researcher (...) I have a quite normal family, or maybe it is a strange family, if you compare it with what was taking place 30 years back. I have two fathers; they are called Ernst and Emil. I have two siblings, and we are all adopted. It has not been very easy to grow up with two fathers, but it is just like anything else I think. 
Before the imagined interview situation, Zoe introduces the essay-readers to her personal observations and thoughts on different familyoriented issues. Among other things, she tells readers:

Women are getting more and more rights (...) and in many countries you are allowed to marry your own sex. I do not know really if I think that what has changed is good. For example the fact that you can marry your own sex, but I do not support that (...).

Even if the essay's endnote instructs readers that her writing is restricted to present-day realities, and that 'the rest is fantasy', Zoe's future 'fantasy' represents interesting material. Zoe, who also says that things 'change too fast', balances between a sober account of a future family's everyday life and personal discomfort with family values and sexual identities of present-day and upcoming society. From a Faroese insider perspective, it is easy to apprehend her youth conservatism, and to presume that her scenario resonates with the contemporary debate on (Faroese) family values and sexuality, a lively and polemic debate with strong (Christian) religious elements. In another essay, written by Robert from Torshavn, we meet a boy called Ólavur. Robert has taken the role of a kind of ethnographer doing participant-observation in the capital of the Faroes in 2045. In his essay (or 'field notes'), he writes:

Ólavur went home and one of the mothers had prepared pizza in their stone oven. Ólavur had no father, but two mothers, because the mothers were homosexual. There was nothing strange about that. Ten years earlier [2035], legislation allowing homosexual couples to marry had been adopted, and two years later Ólavur's mothers married (...).

After longstanding controversy, the Faroese same sex marriage law was finally effectuated in July 2017, much earlier than in Robert's narrative. In many essays, young people draw an image of the normalization of what used to be taboo. In Robert's text, there is no explicit moral judgement of future society, which is characterized by alteration: Ólavur has Spanish classes in lower secondary school (new), the teacher is teaching through the Internet (new), Ólavur does water polo after school (new), and he has a pair of married female parents (new). In the excerpt from the essay, Robert mentions the (homemade) stone oven pizza and the same sex married couple, both nonexistent at the time of writing yet linked to future styles of living, which-together with, for instance, the Spanish classes and water polo-might well refer to trendy styles from TV series and other (foreign) media productions. His scenario, and the 'nothing strange about that' comment to the reader, can be interpreted as a report stressing a fast and irreversible development in society, pushing the Faroes towards the 'realities' of international media. Tina from Torshavn employs sarcasm in her essay's 'slippery slope' argument:

People are for sure going to get more and more rights, more than ever before (this is almost only true for Europe). You will most likely be allowed to marry anyone you like to marry-same sex, more than just one person, and if you like, even an animal.

Tina's essay presents a predominantly negative image of the future, focusing on human and cultural degeneration. Her image of future marriage, echoing youth conservative rhetoric 
with future moralizing, is a warning about what happens when the moral 'floodgates' of society are opened. It disintegrates the Faroese family 5 . The question of religion and culture is also combined with family matters in essays focusing on mixed couples in future society. Daisy from East Town meets a student on her magic travel to the future.

The mother of the student that I met was from the Philippines. She is not the only one; approximately a quarter of all women in the Faroe Islands are from the Philippines or other places. The reason for this is that there are far more men than women in the Faroe Islands, and that more and more men have chosen to get foreign wives in the future (...).

This excerpt from her essay represents a scenario based on an estimation of the result of current trends, if they continue without interruption. The largest groups of non-Nordic female citizens in the Faroes are from Thailand and the Philippines (growing from just eight women in 1990 to a total 240 women in 2018), and international migration has been an important topic in the local media for some years now ${ }^{6}$. Some of the participants, expressing negative sentiments towards non-European and nonChristian immigrants, are worried about the demographic and ethnic shift. 'I just imagine that there are going to be really many dark kids', says a girl from East Town. Other participants consider the multicultural family to be part of a bright future for their society. These young people seem to be able to spot what Bertrand de Jouvenel has called 'futuribles', which are 'descendants of the present' (Staley 2002: 86). The scenarios of, for example, a society with many cross-cultural marriages, will only be considered futurible if we already today can see foreign women or men in the Faroe Islands. The transformation of the Faroese family is, according to young people, an obvious element of any future projection taking contested and controversial present-day tendencies to a new level, but what kind of scenarios are we witnessing concerning the culture and language of the Faroes? What is going to happen, and what is happening already now?

\section{CULTURAL FUTURES}

The future, says Arjun Appadurai, should be studied as a cultural fact; and futurity, rather than the past, should be at the 'heart of our thinking about culture' (2013: 188-189). Present-day practices and decisions are according to him largely based on interpretation of their role and meaning for future scenes. Culture and language serve as main points of identification for most Faroe Islanders, and it is obvious that much writing anticipates scenarios of fragmented and contested futures. Most young people do not expect old traditions to 'finally' disappear, even if change is indeed anticipated. People will still eat dry-aged fish and other Faroese specialties, but there is some uncertainty about the future of the controversial whale hunt. Will Faroe Islanders continue to catch and eat pilot whales as has been done for a thousand years now? Some say that the pollution of the oceans will make it too dangerous for humans to eat the meat and blubber of the whales. Others believe the whaling will stop anyway. Faroe Islanders, says a young person reminding us of the islanders' resilience, 'still celebrate Ólavsøka [National festival], wear national costumes during feasts, and dance the Faroese ring-dance'. May, from East Town, travels forward to 2045 where she engages in conversation with an eighth grader from a village. 
Then I ask him, if they still dance the traditional (circle) dance and sing the accompanying ballads, and such things, and he answers yes, they do, and he does not expect it to end yet, at least (...) because Faroe Islanders have always danced the Faroese dance, so this will continue.

In this image, the circle has no end, thus the dancing will always be practiced, and the future is an echo of the past. In other words, as long as there are Faroe Islanders, there will be a Faroese dance $^{7}$. Remembering is an important part of the imagination process, and like the gardener at work, people select what to be pruned, dug, and sown, hence also what flower will bloom tomorrow (Augé 2004). Rita from East Town, who imagines that only five of the islands (compared to seventeen out of eighteen today) will be permanently inhabited in 2045, has a positive vision for the Faroese dance.

A lot of effort has been made to keep the Faroese dance alive, and therefore culture has gained a great deal of space in the school (...) by teaching the children to sing the ballads and dance the Faroese dance, it has also really gained ground among Faroe Islanders. A lot of activities are initiated in order to keep [the Faroese dance] at this level, because such a dance can quickly lose ground.

Rita's future image describes the status in 2045 as the fruits of a successful 30-years cultural project, which was necessary in order to restore the traditional dance's high position in society. Her input focuses on the potential of the future, the capacity to move and adjust a derailed future. Inspiration for this scenario is found in today's discussion on Faroese culture and education, which for a decade or more has been characterized by efforts to revitalize and renationalize a 'threatened' culture in the Faroese school and national media. Rita, conversely, can motivate and empower people aiming for this future by bringing oracular future scenarios to their minds. In many essays, young people demonstrate that they dare to dream of alternative and contested futures, of futures that turn current trends in 'impossible' directions. A girl criticizing technological trends says that it is imaginable that Faroe Islanders will 'return back to the point where people care about each other and are not living dead in front of the screen'. Penny from East Town, who recapitulates a future teenage girl's description of life in 2045, narrates about language and identity:

The culture has changed a bit, now Faroe Islanders eat much less whale meat, and the language has changed slightly, we don't speak 'stone Faroese' anymore, English and Danish have blended into the Faroese language. There are now just a few farmers in the Faroe Islands (...) I think that in a few years, no one will be able to talk, because it will not be necessary to know how to talk, because then people will just be writing to each other, on Facebook or something similar (...).

Penny reflects on change at two levels-local and global-with a focus on language and communication. The Faroese language will regrettably vanish as a 'pure' independent language, she says, but this becomes trivial when you look at the next nihilist problem: the image of the termination of human verbal communication. Penny also touches upon the precarious and emotional whale issue, which many young people have written about, for instance, Ralph from Torshavn. Ralph, visiting 
2045, an altered world, meets a boy called Markus, who tells him many strange things.

He told me that it was good [to live in 2045], but his mother had told him that it was better to be young 30 years ago, because at that time people came together more, and times were better than now. Markus also told me that the whale hunt was just about to stop, because people had received so much information about dangers associated with whale meat consumption, because there is so much mercury in whales, which influences the learning ability of children. If a woman is pregnant, and she eats whale meat, then the risk of getting a child with a fault, for instance Down's syndrome, increases.

What he says about the whales is not news; we actually hear the same things today. The whale hunt has been 'just about to stop' for a while now, but it is still alive ${ }^{8}$. Ralph's point is probably that in 2045 people will have more knowledge and experience with tragic casestories (strengthening the hypothesis) than what is the case today. Wendy from Torshavn draws the following scenario regarding culture and language.

Faroese culture is strongly influenced by other countries. We have adapted to cultures from other countries-the USA is a good example (...) Almost all the songs and movies are in English, and especially on the Internet, you will have to read and write English almost everywhere. The language is a large part of the Faroese culture, and it is a shame that Faroe Islanders' reading and writing in their own language is so bad.
Like Ralph, she tends to summarize some of the same 'problems' that present-day Faroe Islanders are facing and discussing. Rather than creating an image turning the trend, she considers the future to follow the trajectory already mapped. The language is under attack and the Internet is one of the main menaces. Tomorrow is full of uncertainty for any individual, as a Faroese proverb (reiterating universal wisdom) instructs with this message: 'No one knows in the morning, where he may spend the night'. You never know what tomorrow will offer.

\section{TECHNOLOGICAL FUTURES}

In many of the creative narratives, the image of the future of the (Faroese) culture is influenced by reflection on technological developments. While the cultural scenario focuses on the islands and their history, the image of technological progresses is associated with universal and often 'out of reach' mechanisms. Technology is the two-edged sword that incubates ambivalent scenes of utopia versus dystopia. The constant introduction of new cutting-edge devices and systems contributing to the emerging computerized society, with robotics as part of everyday life, is something all participants in critical reflection try to give a temporal context. Jenny, a concerned girl from East Town, says that humans risk making themselves redundant in an imagined extremely technology-rich future.

If technological development continues to progress $100 \mathrm{~km} / \mathrm{h}$, I have often wondered how the future will look. Sometimes I feel frightened of the thought of us human beings being 'substituted' by appliances/ machines (possibly robots), and these appliances will do the work, and humans 
will not be necessary as a workforce. It is not unimaginable that humans surrender against technology? (...) If this happens, what shall we then spend everyday life doing?

Such technologically determined future narratives, based on the feeling of alienation and powerlessness in a posthuman future of misanthropy, touch on existential and ontological dilemmas. Jenny addresses universal questions shared by a youth generation beyond the Faroes and the Nordic region. Even if many Faroe Islanders have big hopes for the future, some saying that they are 'longing for the future', like a person hungry for new adventure, they also need to reflect on imagined worst-case scenarios. What if what is undesirable today materializes in the small and harmonious North Atlantic community? Ian from Torshavn, like many of his peers, connects discourses on new technology to the future of schooling and education.

Now all cars were flying, scooters and even bicycles were flying, the houses have also changed a lot, with several floors and essentially just glass, and not least people's colourful clothing style. The youth has changed a lot too; I met a boy called Danjál, a very smart boy going to Thor's School, which was a school for the brightest pupils. It was a very expensive school (...) Danjál told me that eighth graders in Thor's School could chose if they wanted Faroese [as a subject], because the teaching was in English. He himself opted out Faroese, because he had plans of going abroad to work, because opportunities were better, and therefore it was important to be fluent in English.
In this exotic future scenario, private schooling for the élite has been introduced to the Faroes, something representing a radical shift from educational realities in Ian's own youth 'back in 2014'. Ian draws a colourful scenario, which interacts with present-day realities through the medium of popular culture in modern mediarepresentations from mainstream film, music, computer games, etc. Ian does not hide his joy of returning to 2014 when he says: 'Good not to be forced to be so far ahead in time, even if it was an interesting trip'. In Ann's odyssey to 2045 , her alter ego says that it is very boring to observe people (in 2045), and triumphantly, that she feels very happy not to 'be addicted to all this electronic junk'. Most contemporary young people are neither fatalistic futurepessimists, nor romantics desperately longing for the 'good old days'. In the interviews and essays, they emphasize that people can change the course of events, find new trajectories, if they use their rights and liberties to counteract dominant tendencies. While some provocative future scenarios from the essays might be interpreted as pure 'science fiction', futuristic without comprehensible historic antecedents, and hence also curious as experiment of altered imagination of Faroese futures, you could also say that tomorrow's technological realities are todays figments.

From this perspective, future imagination also functions as a thought experiment and enigmatic forecast of alternative 'best of thinkable worlds'. Additionally, from another angle, future imagination gives present-day trends a value and temporal context ${ }^{9}$. Young people's future images beacon hidden danger ahead, but why worry? The creative narratives are full of descriptions of isolation and social and psychological distress as side effects of new digital everyday lives, as when, for instance, 
Daisy regretfully says that 'we lose contact with other people, and with all the beautiful things happening around us', if we just focus on the screen. In Tommy's case, readers are warned about digital media's corruptive power. 'People get lazier with every passing day, every day that goes', he says with great apprehension. Young people, maybe more than their parents, appreciate new technologies influencing their everyday lives, but they are at the same time critically aware of their adverse effects, if not carefully adapted to local culture and life. In the turmoil of social and physical forces, people attempt to make life 'as certain as possible' (Gaffin 1987: 329).

\section{ISLANDS AND COLLECTIVE FUTURES}

We have seen in the material from the essays that storytelling, based on the past or on the future, is highly appreciated among Faroe Islanders (Wylie 1987). 'A new idea can suddenly revolutionize the world', says a girl in her essay, "like the Industrial Revolution, which deeply transformed the world'. Others, pointing to time/space fragmentation in the globalized world, say that perhaps the apocalyptic Earth does not exist in 2045. 'Maybe this was just a dream', a girl tells the reader allegorically in the last passage of her essay, 'a dream where everything had changed, the Faroes had become a totally different country, and I thought that maybe the dream was not so distant from reality after all'. The unrealistic was reasonable. In the end, says a contemplative girl, it does not matter (referring to the technological futures), 'because we are all going to leave this place as naked as we entered it'. Another girl says that she prefers the Faroes like it is now, because 'I guess you always prefer what you are used to and feel safe with'. Clearly, most young Faroe
Islanders embrace what is familiar and durable. It is exciting to navigate to the future, but it is even more satisfying to return home to presentday realities. The future, in other words, is great to think with, to use for mental escapades and veiled critique of present-day issues (Abram 2017). The not-yet-now is first exoticized and then de-exoticized (Bryant and Knight 2019). Altering the islands, without craving foretelling, young people prepare for complex questions and decisions to confront and handle tomorrow.

As we have seen in the teenagers' creative narratives, the future is often drawn as altered islands-a mesmerizing breakaway from present-day realities. The opportunity to dream and to imagine tomorrow is an important part of teenagers' everyday life practices and identities. The Faroes, with its combination of smallness and complexity, continue to be a place of maybe, despite the influence of processes of modernization and globalization ${ }^{10}$. The islanders keep affixing the maybe to any articulation of tomorrow's realities. The cultural maybeism of the Faroe Islanders, combined with the alerts linked to future imagination, produces an interesting temporal collage, with images from the past, the present, and the future in creative composition. In our ambiguous time, with short-term focus on crises and oblivion, says futurist Richard Slaughter (2003), we need to explore and map 'near-future landscapes', which can help us navigate more carefully into the future. As a canary in the coalmine, he says, young people might well represent a special group with visions otherwise disguised from the public debate. According to many of the essays, we are going to witness deep change, but something is going to remain in the turmoil. The bundle of so-called futuribles at hand does indeed nudge the youth, giving them the material to encounter, bend, and reshuffle the creative maps of the future, but, as we have seen 
in the narratives, young islanders do also engage in active reversal of these projected futures. With alternative styles of imagination, they are uprooting (and mixing) the seeds (futuribles) to sow tomorrow.

We have seen that young islanders' critical reflection on temporal past/future dynamics of their society tends to draft a kind of 'simplified, exaggerated version' (Quammen in Baldacchino 2007: 14) of large-scale continental social processes, which they thereafter creatively reshuffle in different future scenarios ${ }^{11}$. As islanders, young people from the Faroes present the future as an (insular) place essentially different from other islands. In this optic, future shift departs from alien shores, like some kind of temporal driftwood of obscure origin. Looking at the future as an alterity of the present, we study young people playing with blurred boundaries and inverted landscapes, testing the relation between lived experience and fiction. 'People have always been interested in the future', says a Faroese boy, and 'the future is something big in your life'. The future symbolizes the opening of a closed insular field, a gateway to the surrounding world, yet also, as resonated in the collection of essays from the Faroes, a refraction of a long line of social and cultural progression. The remoteness and insularity of the islands suggests "being on the edge, being out of sight and so out of mind' (Baldacchino 2006: 6). Therefore, future imagination among islanders is also a part of the everyday struggle for recognition and cultural emancipation in the 'periphery'.

The infrastructure of uncertainty, as expressed in everyday life maybe-ism, does not imply a lack of passionate engagement in issues affecting future society. The essays clearly demonstrate that Faroe Islanders do take their future seriously, and that they have visions and missions for their islands. Future imagination also represents a struggle for the right to define your own future culture and society, individually and as a collective (Klein 2018). We have seen that young people's creative narratives produce a parallel and contested version of the future(s) resting on the pillar of the history and culture of the place. The vision of a common island future gives young people individual strength and integrity (Augé 2014: 106). In an overheated world of risk, where many people, by a sort of osmosis, absorb the idea of a caged (unavoidable) future, young islanders seem to escape temporal tautologies and embrace contingent future worlds. Fixing their gaze upon the future in creative written narratives, Faroe Islanders identify and reinterpret their cultural identity, their sense of belonging to a place, and their history.

\section{NOTES}

1. This Faroese project served as a contribution to an international ethnographic project focusing on young people's future perspectives in the Nordic/ Arctic region (Faroe Islands, Greenland, Iceland, Norway, Sweden, and Finland), representing a component of the 'Foresight Analysis for Sustainable Regional Development in the Nordic Arctic' programme (Karlsdóttir and Jungsberg 2015).

2. Most Faroe Islanders are Christians, of which more than three-quarters are members of the national Lutheran Protestant church. The Faroe Islanders were subjugated to Norwegian rule for eight centuries (1030-1814) before they came under Danish rule. In 1948, a Home Rule resolution was introduced in the Faroe Islands. Since modernization and industrialization came very late to the North Atlantic region, the Faroes represented some sort of feudal remnant on the rim of Europe until the end of the $19^{\text {th }}$ century, when intensive fishing from cutters started. The Royal Danish Trade Monopoly was abolished in 1856 , opening the way for free commercial 
activities and market capitalism in the Faroes. In the 1960s, large investments in a modern fishing fleet made the Faroese fishing industry one of the most efficient and profitable in Europe.

3. Today's general image of the Faroes is bright with self-representations emphasizing shared vigorous efforts to create a wealthy and forward-looking society. The economic growth of the last couple of years, with hugely successful export-oriented salmon farming and other fisheries ventures, has led to population growth, declining rates of unemployment, and massive investments in the infrastructure (schools, roads, tunnels, retirement homes, etc.) of the Faroes.

4. The Faroese kanska, which has many facets and connotations, displays everyday communication's dynamic social character, but it is also a statement symbolically opposing temporal 'confinement'. While maybe can say 'depending on the weather (or on God)', it can also signify 'depending on what neighbours and relatives suggest'.

5. Almost 85 per cent of the Faroe Islanders are members of the Faroese Evangelical Lutheran (State) Church, which includes the Inner Mission (probably about 10-15 per cent of the population). Around 15 per cent belong to the Calvinist-inspired Plymouth Brethren. The Faroes have a very high rate of believers compared to the other Nordic countries, and many young people from all layers of society have adopted neo-evangelical Protestantism as their identity (Pons 2011). The free churches, with members considering themselves to be 'true believers' in contrast to the State Church's secularized and laid-back 'Christians by tradition' who 'belong without believing', represent various associations that-in some cases-are in strong competition with each other (ibid.).

6. In the debate, the longstanding 'problem' of Faroese women moving abroad without returning home, which has resulted in a society with a lack of women (compared to the number of men), is linked to the 'solution' of a growing number of predominantly Asian and African women moving to the Faroes for marriage with local Faroese men. Women's out-migration is largely a consequence of the general lack of attractive working and educational opportunities in the Faroes (especially in rural communities) as well as the conservative 'masculine' values limiting their personal life projects (Gaini 2008).
7. The Faroese ring-dance (usually called circle or chain dance in English), accompanied by old ballads, is a mediaeval Central European ring dance, which disappeared from other countries centuries ago. Faroe Islanders still dance and sing in this way (especially at wedding parties, national festivals, and other special occasions).

8. The Faroese hunt of long-finned pilot whales, dating back to the Viking era, is controversial and has been heavily criticized as barbaric and unethical by various international organisations, some of which have pushed for boycott of Faroese products.

9. 'How beauteous mankind is! O brave new world', Miranda says excitingly in Shakespeare's The Tempest, but Brave New World is also the ironic title of Huxley's Dystopian novel, presenting systematic universal indoctrination as a part of futurist social 'projects', and ridiculing early $20^{\text {th }}$ century novels with naïve Utopian visions (Huxley 1932). Many of the participants' essays, more or less explicitly, reflect on dystopian/ utopian facets (as two sides of the same coin) of convoluted future images.

10. In the 'Land of Maybe', with all the uncertainties concerning the surrounding nature and its resources, it was never easy to prepare for recession and crisis. The periodical Foroyingatidindi proclaimed in an optimistic editorial (from February 1893) that 'Faroese will devote all their energies to making progress at sea and shore (...) so that people can have a good future before them in their homeland' (quoted in Wylie 2011:23). However, in 1936 the Country Medical Officer wrote about the difficult situation in the country:

'The people of the Faroes are by nature very frugal and have always shown great ability to adapt, but now they have reached a minimum below which it is impossible to exist. The population is in the grip of a psychological depression and seems to have lost faith in the future. Faith that bright days will dawn again. The day fades in sighs, and the next dawns in despair. Mothers dare not give birth to new lives, and the birth rate is falling, in spite of general rise in population (...) It is not surprising that it is difficult to keep spirits up, and to look to the future with bright hopes' (in Joensen 1995: 93).

Asking young people to write their future images in 1936 would most likely have produced scenarios of a quite different nature than what we have seen in my project. 
11. Futures, which in neoliberal globalization are claimed to be locked up (Tsing 2005), can also be viewed as a temporal 'tourist destination' based on so-called 'tourist imaginaries' (Salazar in Andrews 2017:33). These imaginaries, disseminated through media, produce a reality 'that simultaneously produces it' (ibid.).

\section{REFERENCES}

Abram, Simone 2017. Contemporary Obsessions with Time and the Promise of the Future. In Salazar et al. (eds) 2017.

Andrews, Hazel 2017. Becoming through Tourism: Imagination in Practice. Suomen Antropologi: Journal of the Finnish Anthropological Society 42 (1): 31-44.

Appadurai, Arjun 2013. The Future as Cultural Fact: Essays on the Global Condition. London and New York: Verso.

Augé, Marc 2004. Oblivion. London: University of Minnesota Press

Augé, Marc 2014. The Future. London: Verso

Austdal, Tord and Espen Helgesen 2015. Introduksjon: Fremtidsforestillinger. Norsk Antropologisk Tidsskrift 26 (3-4): 208-220.

Baldacchino, Godfrey 2006. Editorial: Islands, Island Studies, Island Studies Journal. In Island Studies Journal 1 (1): 3-18.

Baldacchino, Godfrey 2007. Introducing a World of Islands. In Godfrey Baldacchino (ed.). A World of Islands: An Island Studies Reader. Prince Edward Island: Agenda Academics and Institute of Island Studies.

Bauman, Zygmunt 2006. Living in Utopia. Soundings 33: 13-23.

https://doi.org/10.3898/136266206820466318.

Bryant, Rebecca and Daniel M. Knight 2019. The Anthropology if the Future. Cambridge: Cambridge University Press.

https://doi.org/10.1017/9781108378277.

Cole, Sam 2001. Dare to Dream: Bringing Futures into Planning. Journal of American Planning Association 67 (4): 372-383.

https://doi.org/10.1080/01944360108976246.
Erikson, Erik H. 1964. Insight and Responsibility. New York: WW Norton.

FEC 2012. Economic Report (Faroese Economic Council) Autumn 2012.

https://www.setur.fo/media/1071/busr_2012autmn_ en.pdf. < Accessed in November 2018>

Gaini, Firouz 2008. Midlar, Mentan og Seinmodernitetur. Ein antropologisk lýsing av foroyskum ungdómi. Torshavn: Faroe University Press.

Gaini, Firouz 2015. Wherever I Drop Anchor: Faroese Teenagers' View on Future Home and Migration. Fródskaparrit 62: 52-69.

https://doi.org/10.18602/fsj.v62i0.22.

Gaffin, Dennis 1987. Everyday People as Living Legends: The Art of Social Control in a Faeroese Village [dissertation]. Buffalo: State University of New York

Gaffin, Dennis 1996. In Place: Spatial and Social Order in a Faeroe Islands Community. Prospect Heights: Waveland Press

Galland, Oliver 2008. Young People and Society: Contrasting Visions of the Future. In Anna Stellinger (ed.). Young People Facing the Future: An International Survey. Paris: Fondation pour l'innovation politique.

Greene, A. L. and Susan M. Wheatley 1992. 'I've Got a Lot to Do and I Don't Think I'll Have the Time': Gender Differences in Late Adolescents' Narratives of the Future. Journal of Youth and Adolescence 21 (6): 667-686.

https://doi.org/10.1007/BF01538738.

Hayfield, Erika Anne 2017. Exploring Transnational Realities in the Lives of Faroese Youngsters. Nordic Journal of Migration Research 7 (1): 3-11. https://doi.org/10.1515/njmr-2017-0007.

Hirsch, Eric and Charles Stewart 2005. Introduction: Ethnographies of Historicity. History and Anthropology 16 (3): 261-274.

https://doi.org/10.1080/02757200500219289.

Hovgaard, Gestur and Richard Apostle 2002. Case Studies of Socioeconomic Change: Analytical Concerns. In R. Apostle, D. Holm, G. Hovgaard, Ó.W. Høgnesen, and B. Mortensen 2002. The Restructuration of the Faroese Economy. Frederiksberg: Samfundslitteratur 
Huxley, Aldous 1932. Brave New World. London: Chatto \& Windus.

Ingold, Tim 1993. The Temporality of the Landscape. World Archaeology 25 (2): 152-174. https://doi.org/10.1080/00438243.1993.9980235.

Joensen, Jóan Pauli 1995. The Passbook: The Truck System in the Faroe Islands 1856-1939. Ethnologia Scandinavia vol 25.

Karlsdóttir, Anna and Leneisja Jungsberg (eds) 2015. Nordic Arctic Youth Future Perspectives. Stockholm: NORDREGIO.

Klein, Naomi 2018. The Battle for Paradise: Puerto Rico Takes on the Disaster Capitalists. Chicago: Haymarket Books.

Knight, Tony 2017. Pyrenean Rewilding and Colliding Ontological Landscapes: A Future(s) Dwelt-in Ethnographic Approach. In Salazar et al. (eds) 2017.

Mead, Margaret 1971. A Note on Contributions of Anthropology to the Science of the Future. Human Futuristics 3. Honolulu: University of Hawaii.

Norgate, Sydney 1943. 'Kanska' or The Land of Maybe. Torshavn: HN Jacobsens Bókhandil

Persoon, Gerard A. and Diny M. E. van Est 2000. The Study of the Future in Anthropology in Relation to the Sustainability Debate. Focaal 35: 7-28.

Pink, Sarah, Yoko Akama and Annie Fergusson 2017. Researching Future as an Alterity of the Present. In Salazar et al. (eds) 2017.

Pink, Sarah and Juan Francisco Salazar 2017. Anthropologies and Futures: Setting the Agenda. In Salazar et al. (eds) 2017.

Polak, Fred 1973. The Image of the Future. Michigan: Elsevier Scientific Publishing Company

Pons, Christophe 2011. The Anthropology of Christianity in the Faroe Islands. What the Fringes of the Faroese Religious Configuration Have to Say about Christianity. In Firouz Gaini (ed.). Among the Islanders of the North: An Anthropology of the Faroe Islands. Torshavn: Faroe University Press

Salazar, Juan Francisco, Sarah Pink, Andrew Irving and Johannes Sjöberg (eds) 2017. Anthropologies and Futures: Researching Emerging and Uncertain Worlds. London: Bloomsbury Academic.
Slaughter, Richard A. 2003. Futures Beyond Dystopia: Creating Social Foresight. London: Routledge. https://doi.org/10.4324/9780203465158.

Staley, David J. 2002. A History of the Future. History and Theory 41 (4): 72-89. https://doi.org/10.1111/1468-2303.00221.

Toffler, Alvin 1970. Future Shock. New York: Random House.

Trell, Elen-Maarja and Bettina van Hoven 2010. Making Sense of Place: Exploring Creative and (Inter)active Research Methods with Young People. Fennia: International Journal of Geography 188 (1): 91-104.

Tsing, Anna 2005. Friction: An Ethnography of Global Connection. Princeton (NJ): Princeton University Press.

Urry, John 2016. What Is the Future? Cambridge and Malden (MA): Polity Press.

Valentine, David 2012. Exit Strategy: Profit Cosmology, and the Future of Humans in Space. Anthropological Quarterly 85 (4): 1045-1068. https://doi.org/10.1353/anq.2012.0073.

Wallman, Sandra (ed.) 1992. Contemporary Futures: Perspectives from Social Anthropology. London and New York: Routledge

Wylie, Jonathan 1982. The Sense of Time, the Social Construction of Reality, and the Foundations of Nationhood in Dominica and the Faroe Islands. Comparative Studies in Society and History 24 (3): 438466. https://doi.org/10.1017/S0010417500010082.

Wylie, Jonathan 1987. Interpretations of History. Kentucky: University Press of Kentucky.

Wylie, Jonathan 2011. Eg Oyggjar Veit? Views, Overviews, and Overisghts. In Firouz Gaini (ed.). Among the Islanders of the North: An Anbtropology of the Faroe Islands. Torshavn: Faroe University Press.

FIROUZ GAINI

PROFESSOR IN SOCIAL ANTHROPOLOGY DEPARTMENT OF HISTORY AND

SOCIAL SCIENCES

UNIVERSITY OF THE FAROE ISLANDS

firouzg@setur.fo 